\title{
Działania organów bezpieczeństwa i porządku publicznego jako formy prewencyjnego ingerowania w wolność wypowiedzi
}

Sytuacje charakteryzowane jako ograniczenie wolności wypowiedzi

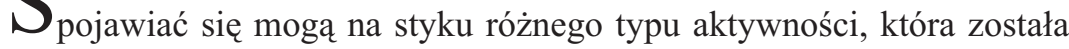
nakazana przez prawo, ale także takiej, która jest prawnie zakazana, dozwolona albo prawnie indyferentna ${ }^{1}$. Czyny nakazane lub zakazane, których przedmiotem jest wolność wypowiedzi, stosunkowo łatwo można zidentyfikować i ocenić pod kątem naruszenia granic wolności wypowiedzi. Trudniejsze do zidentyfikowania są te formy naruszenia wolności wypowiedzi, które pojawiają się na styku realizacji obowiązków, uprawnień bądź kompetencji wykonywanych przez organy władzy publicznej odpowiedzialnych za ochronę bezpieczeństwa i porządku publicznego wobec osób, które indywidualnie lub zbiorowo korzystają z wolności wypowiedzi, przekazując informacje lub demonstrując publicznie swoje przekonania i opinie w ramach organizowanych zgromadzeń albo wykorzystując do tego środki masowego przekazu².

1 Z. Ziembiński kwalifikuje tego rodzaju czyny jako indyferentne prawnie, co oznacza, że normy prawne ,,ani bezpośrednio, ani pośrednio nie nakazują ani nie zakazują [działania]" (Z. Ziembiński, Analiza pojęcia czynu, Warszawa 1972, s. 169).

2 Pojęcie ,środków masowego przekazu” występuje w doktrynie i literaturze obok pojęcia „środki masowego komunikowania”. Inni badacze preferują użycie określenia „mass media” (zob. T. Goban-Klas, Komunikowanie masowe, Kraków 1978, s. 19). J. Sobczak zauważa, że używane jest także, aczkolwiek z rzadka definiowane, pojęcie: „środki społecznego komunikowania” oraz „środki komunikowania politycznego" (J. Sobczak, Prawo prasowe. Komentarz, Warszawa 2008, s. 70). W art. 14 Konstytucji (ustawa z dnia 2 kwietnia 1997 r., Dz. U. Nr 78, poz. 483 z pózn. zm.) ustrojodawca użył pojęcia „środki społecznego przekazu”. Kodeks karny (ustawa z dnia ustawa z dnia 6 czerwca 1997 r. Dz. U. Nr 88, poz. 553 z późn. zm.) w art. $212 \S 2$ posługuje się tymczasem określeniem ,środki masowego komunikowania". Do środków masowego przekazu zostały zaliczone prasa i internet (J. Sobczak, Prawo..., s. 319), a także, przy pewnych oporach, publikacje książko- 
Zdaniem niektórych autorów, wolności, w równym stopniu co prawa, wymagają aktywnych, gwarancyjnych i ochronnych działań ze strony państwa i jego organów ${ }^{3}$. Konsekwencją ograniczania wolności wypowiedzi, groźną dla demokratycznego systemu sprawowania rządów, jest bowiem obezwładnienie innych wolności i praw politycznych. W doktrynie zwraca się uwagę, że pełni ona funkcję zabezpieczającą istnienie takich praw jak w szczególności wolność gromadzenia się (art. 57 Konstytucji $^{4}$, wolność publicznego wyrażania przekonań religijnych, światopoglądowych i filozoficznych (art. 25 ust. 2 Konstytucji), wolność zrzeszania się (art. 58 Konstytucji), a także gwarantuje realne korzystanie z czynnego prawa wyborczego oraz prawa głosowania w referendum (art. 62 Konstytucji) $)^{5}$. J. Sobczak zauważa, ze większość autorów przyznaje pierwszeństwo wolności wypowiedzi w kwestiach publicznych przed ewentualnymi wolnościami, prawami i wartościami, z którymi wolność ta mogłaby wchodzić w kolizję ${ }^{6}$ Szczególne znaczenie wolności wypowiedzi, pozwala przyznać jej „,dodatkową odporność na jakiekolwiek ograniczenia. Konsekwencją ograniczenia wolności wypowiedzi jest bowiem natychmiastowe, niemal automatyczne ograniczenie innych wolności i praw [...]. Powiada się zatem, że jedyną bezsporną przesłanką

we, plkaty, bilboardy itd. Jak zauważa J. Raglewski nie chodzi bowiem o masową dostępność samego medium, lecz o masową dostępność informacji przekazywanych za jego pomocą (J. Raglewski, Komentarz do art. 212 k.k., w: Kodeks karny. Część szczególna, red. A. Zoll, Warszawa 2006, s. 785).

${ }^{3} \mathrm{~W}$ doktrynie formułowane są odmienne stanowiska w odniesieniu do zakresu ochrony i aktywności, jaką państwo powinno wykazywać. Nie budzi wątpliwości, że państwo powinno być prawnym gwarantem wolności wypowiedzi (Zob. ibidem, s. 98). Postuluje się jednak, by obowiązki państwa w zakresie ochrony praw i wolności człowieka polegały nie tylko na powstrzymaniu się przed ingerencją (zob. A. Frankiewicz, Regulacja wolności wypowiedzi w polskim porzqdku prawnym, w: Prawa $i$ wolności obywatelskie w Konstytucji RP, red. B. Banaszak, A. Preisner, Warszawa 2002, s. 361), ale także na podjęciu aktywnych działań zarówno gwarancyjnych, jak i reglamentacyjnych. Analizując obowiązki państwa w odniesieniu do wolności wypowiedzi i wolności prasy W. Sokolewicz wyraża pogląd, że ,władze publiczne są wręcz zobowiązane do użycia wszelkich środków prawnych, regulacyjnych i innych przewidzianych przez prawo, aby zagwarantować rzeczywistą wolność prasy w kraju, nawet kosztem ochrony prywatności pewnych kategorii osób" (zob. W. Sokolewicz, Prasa i Konstytucja, Warszawa 2011, s. 62).

4 Ustawa z dnia 2 kwietnia 1997 r., Konstytucja Rzeczypospolitej Polskiej,

Dz. U. Nr 78, poz. 483 z pózn. zm.

5 W. Sokolewicz, Prasa..., s. 67 i 68.

6 J. Sobczak, Prawo prasowe. Komentarz, Warszawa 2008, s. 79. 
ograniczeń wolności wypowiedzi jest wykorzystywanie jej do zachęcania użycia przemocy" ". Stanowisko to w niewielkim stopniu koresponduje jednak ze ścisłą wykładnią norm prawnych dokonywaną przez orzecznictwo. Staje się to szczególnie czytelne, jeśli regulacje deklarujące ochronę wolności wypowiedzi (art. 54 Konstytucji) są interpretowane w łączności z przepisami limitującymi jej zakres w prawie krajowym (art. 31 ust. 3 Konstytucji) i ponadnarodowym.

Nominalne gwarancje wolności wypowiedzi należy odróżnić od faktycznie istniejących możliwości z niej korzystania ${ }^{8}$. Podobnie, odróżnienia wymaga wprowadzenie - w sensie nominalnym - ograniczeń wolności wypowiedzi od sytuacji faktycznego skutku w postaci jej ograniczenia. Skutek ten może występować pod wieloma, niekiedy trudnymi do uchwycenia postaciami ${ }^{9}$. Zawsze jednak pozostaje pytanie o rolę pań-

7 Ibidem, s. 68.

${ }^{8}$ Wolność wypowiedzi była prawnie zagwarantowana także w okresie stalinizmu w Polsce, a zatem w systemie charakteryzowanym jako reżim totalitarny, a następnie, w czasach poststalinowskich - reżimie autokratycznym. Zarówno w wypadku reżimu autokratycznego, jak i totalitarnego państwo ucieka się do przemocy w stosunku do ludności kraju, a sposób sprawowania władzy pozostawał poza kontrola społeczną (zob. A. Łopatka, Prawoznawstwo. Wprowadzenie, Warszawa 2002, s. 41). Przepisy obowiązującej wówczas Konstytucji PRL (Dz. U. 1952, Nr 33, poz. 232) gwarantowały obywatelom $\mathrm{w}$ art. 71 ust. 1 „wolność słowa, druku, zgromadzeń i wieców, pochodów i manifestacji”. Zgodnie z treścią art. 71 ust. 2 „Urzeczywistnieniu tej wolności służy oddanie do użytku ludu pracującego i jej organizacji drukarni, zasobów papieru, gmachów publicznych i sal, środków łączności, radia oraz innych niezbędnych środków materialnych". Nie przeszkadzało to organom władzy sprawować pełnej kontroli nad rozpowszechnianiem informacji i opinii. Informacja została całkowicie zmonopolizowana, a dziennikarze byli wykorzystywani, zwłaszcza w okresie instalowania systemu komunistycznego w Polsce, do celów werbunkowych - chodziło o pozyskanie społeczeństwa do współpracy z władzą (zob. W. Suleja, Dziennikarz w Polsce Ludowej i PRL - kontestator i funkcjonariusz rezimu, w: Wolne media? Środowisko dziennikarskie w 1989 roku, red. P. Szulc, T. Wolsza, Szczecin-Warszawa 2010, s. 13).

9 Za ograniczenie wolności wypowiedzi w sensie faktycznym może zostać uznane monopolizowanie przez grupę dziennikarzy dostępu do mediów. Działaniem tym jest także tworzenie programów radiowych i telewizyjnych pomijających chrześcijański system wartości. Formą ograniczania wolności wypowiedzi jest także pomijanie przez Domy Mediowe sprzedaży przestrzeni reklamowej w niektórych tytułach prasowych oraz programach radiowych i telewizyjnych. Działaniem tym jest także, coraz częściej dostrzegany - dyktat mniejszości polegający na nieproporcjonalnej co do zakresu, zasięgu oraz formy prezentacji poglądów skrajnych i niereprezentatywnych dla społeczeństwa przy jednoczesnym przemilczaniu poglądów publicznie wy- 
stwa i stopień koniecznej aktywności wobec faktycznie występujących ograniczeń wolności wypowiedzi, pomimo jej nominalnej gwarancji.

Gwarancję wolności wypowiedzi zapewniają regulacje zawarte w art. 31 Konstytucji RP, w którym wytyczone zostały także jej granice $^{10}$. K. Wojtyczek podkreśla, że przepis ten wyznacza pięć kryteriów dopuszczalności ingerencji państwa w sferę praw i wolności człowieka. Są to: 1) wymóg, aby ograniczenia były ustanowione w ustawie; 2) zasada proporcjonalności; 3) wymóg uwzględniania zasad państwa demokratycznego; 4) wymóg, aby ograniczenia służyły realizacji wymienionych w tym przepisie wartości; 5) zakaz naruszania istoty danego prawa ${ }^{11}$. Ograniczenia wolności wypowiedzi mogą być zatem ustanowione tylko w ustawie i wyłącznie wówczas, kiedy są konieczne w demokratycznym państwie, a konieczność dyktowana jest potrzebą bezpieczeństwa lub porządku publicznego bądź ochroną środowiska, zdrowia i moralności publicznej albo wolności i praw innych osób ${ }^{12}$.

O ile dla legalności wprowadzanych ograniczeń konieczne jest wskazanie ich celu, o tyle a contrario, za niedopuszczalne należy uznać domaganie się określania celu, któremu służyć ma indywidualne lub zbiorowe korzystanie z wolności. Nieuprawniona jest zatem kontrola prewencyjna rozumiana jako niedopuszczanie do publicznego dyskursu wypowiedzi z uwagi na ich nieprawowity cel, zakres bądź formę. Istotą wolności słowa jest wolność od cenzury prewencyjnej rozumianej, jako przyznanie organom państwowym kompetencji do kontrolowania treści wypowiedzi przed ich przekazaniem odbiorcy, a także do uzależniania przekazania wypowiedzi odbiorcom od uprzedniej zgody organu państwowego ${ }^{13}$. Zakaz stosowania cenzury prewencyjnej zawiera art. 54 ust. 3 Konstytucji. E. Nowińska zwraca uwagę, że ze względu na miejsce regulacji, zakaz cenzury prewencyjnej należy traktować jako przynależny do zasad ustrojowych. W tym sensie „cenzura” oznacza kontrolę wypowiedzi pod kątem jej zgodności z polityką władz państwowych i promowanymi przez nie

rażanych w ramach zbiorowych aktów społecznej aktywności. Działaniem tym jest także dobór pracowników mediów, a także niedopuszczanie do emisji już wyprodukowanych programów czy filmów przez niezależnych twórców (np. „List z Polski”; „Operator”), a nawet utrudnienia w dokonywaniu rezerwacji lub wynajmie sal projekcyjnych, w których miało dojść do projekcji tzw. zakazanych filmów.

${ }_{10}$ Wyrok SN z dnia 17 października IV KKN 165/97, OSN 2002, nr 3-4, poz. 28.

11 K. Wojtyczek, Granice..., s. 78.

12 J. Sobczak, Prawo..., s. 80.

13 Uchwała TK z 2 marca 1994 r., W 3/93, OTK 1994 r., nr 1, poz. 17. 
wartościami $^{14}$. Zbliżone rozumienie proponuje T. Goban-Klas przyjmując, że ,cenzura w ścisłym sensie, to znajdujące się w rękach władzy narzędzie kształtowania i utrzymywania oficjalnej wersji prawdy (ideologii)"15.

Zgodnie z poglądem wyrażonym przez Trybunał Konstytucyjny z pojęciem cenzury prewencyjnej należy wiązać nałożenie na podmiot korzystający z wolności wypowiedzi obowiązku przedstawienia do uprzedniej kontroli treści wypowiedzi przeznaczonej do publicznej prezentacji, a zarazem przyznanie $\mathrm{w}$ normach prawnych określonym podmiotom kompetencji do dokonywania takiej oceny ${ }^{16}$. J. Sobczak, powołując się na poglądy doktryny, zwraca uwagę, że zakaz cenzury prewencyjnej „istnieje w tym sensie, że państwo ani nie może tworzyć prawa umożliwiającego cenzurę, ani też nie jest władne powołać organów do jej przeprowadzenia" ${ }^{\prime 17}$. Podnosi się także, że zakaz cenzury sformułowany w Konstytucji jest zakazem istniejącym erga omne, co oznacza, że nie tylko państwo, lecz także żadne inne organizacje nie mogą dokonywać cenzury prewencyjnej i tworzyć jakichkolwiek organów do jej przeprowadzenia, w tym także organów społecznych ${ }^{18}$.

Cenzura prewencyjna jest szczególną formą ograniczenia wolności wypowiedzi, która zawsze jest sprzeczna z prawem i jako taka uznawana jest za niedopuszczalną w systemie demokratycznym. Z definicji, jakie pojawiają się w doktrynie można wnosić, że szczególną cechą cenzury prewencyjnej, która wyróżnia ją spośród innych form ograniczania wolności wypowiedzi, jest obowiązek przedkładania treści wypowiedzi przeznaczonych do rozpowszechnienia oraz istnienie instytucji bądź organów, wyposażonych w specjalne kompetencje do decydowania o zakresie dopuszczalnych publikacji. Ze względu na szczególny status, jaki doktryna, dokonując wykładni pojęcia cenzury prewencyjnej, przypisuje organom władzy publicznej posiadającym kompetencje do kontrolowania treści publikacji, zasadnie jest mechanizm ten nazywać cenzurą instytucjonalną. Cenzura prewencyjna może być zatem utożsamiana z cenzurą instytucjonalną. Wydaje się jednak, że efekt prewencyjnego ogranicze-

14 E. Nowińska, Wolność..., s. 44.

15 T. Goban-Klas, Granice wolności mediów, w: Dziennikarstwo i świat mediów, red. Z. Bauer, E. Chudziński, Kraków 1996, s. 268.

16 Uchwała TK z dnia 2 marca 1994 r., W 3/93, OTK 1994 r., nr 1, poz. 17.

17 J. Sobczak, Prawo..., s. 77.

18 Ibidem, s. 78. 
nia wolności wypowiedzi jest możliwy do osiągnięcia nawet $\mathrm{w}$ tych systemach, w których cenzura instytucjonalna jest zakazana.

W definicjach doktrynalnych, prawdopodobnie ze względów historycznych, położono szczególny nacisk na tryb dokonywania cenzury, a nie na wywoływany efekt. Przyjąć zatem należy, że działania innego typu, choćby podejmowane przez organy władzy publicznej w celu zapobieżenia, wstrzymania lub zmiany treści przeznaczonych do rozpowszechnienia, nie będą mogły zostać uznane za mieszczące się w charakterystyce cenzury prewencyjnej. Należy jednak zauważyć, że efekt cenzury prewencyjnej wywoływać mogą działania polegające na zastraszaniu, nękaniu a także inwigilowaniu, które przez swoją uporczywość i dolegliwość odstręczają od korzystania z wolności wypowiedzi. Efekt ograniczania wolności wypowiedzi może być wywoływany na płaszczyźnie kontaktów pomiędzy jednostką a organami władzy publicznej, a także w sferze pozaprawnej na płaszczyźnie kontaktów i realizacji interesów instytucji medialnych oraz w sferze wydawania rozstrzygnięć indywidualnych na gruncie błędnej wykładni albo niekonstytucyjności przepisów prawa. Konstytucyjny zakaz stosowania cenzury prewencyjnej nie wstrzymuje uruchomienia mechanizmu stosowania cenzury represyjnej, która jest dopuszczalna także w systemach demokratycznych ${ }^{19}$.

Działania wywołujące skutek faktyczny w postaci ograniczania wolności wypowiedzi, można analizować w oparciu o kryterium podmiotu dokonującego ingerencji albo w oparciu o kryterium formy ingerencji poprzez uwzględnienie jej prawnego lub pozaprawnego charakteru. Wydaje się, że najbliższe pojęciu cenzury, a zatem także najgroźniejsze dla demokracji, są ingerencje dokonywane pośrednio lub bezpośrednio przez organy władzy publicznej. Dotyczy to zatem także sytuacji, w których interwencja została podjęta nie tylko $\mathrm{w}$ imieniu, ale także w interesie organu władzy. Należy zarazem zwrócić uwagę, że legalna definicja pojęcia organu władzy ${ }^{20}$ nie zawsze pokrywa się $z$ jego potocznym rozu-

19 Pojęcie cenzury represyjnej jest używane na określenie następczej kontroli treści. W doktrynie zwraca się uwage, że konstytucja nie formułuje zakazu cenzury represyjnej.

20 Przez pojęcie organu władzy publicznej w znaczeniu ścisłym należy rozumieć „wszystkie organy władzy publicznej, a więc zarówno zaliczane do władzy ustawodawczej, jak i wykonawczej oraz sądowniczej, organy wszystkich rodzajów jednostek samorządu terytorialnego, a także organy jednostek wyodrębnionych tylko organizacyjnie w aparacie władzy publicznej (zob. B. Adamiak, J. Borkowski, Kodeks postępowania administracyjnego. Komentarz, Warszawa 2009, s. 21). E. Ochendowski zauważa, że spośród organów władzy publicznej do organów administracji publicz- 
mieniem. W debacie publicznej pojęcie organu władzy obejmuje swoim zakresem nie tylko organy administracji publicznej, ale rozciaga się także na ugrupowanie polityczne, które w danym momencie historycznym sprawuje władzę w państwie. Pojęcie władzy jest zatem odnoszone do ugrupowania politycznego posiadającego legitymację do wyposażania organów administracji publicznej w środki finansowe i kompetencje oraz powoływania kierownictwa tych organów.

Przejawem działań organów władzy skutkujących ograniczeniem wolności wypowiedzi było usunięcie namiotu Solidarnych 2010 z Krakowskiego Przedmieścia ${ }^{21}$, tworzenie barier ochronnych przed grupką osób modlących się pod krzyżem stojącym przed Kancelarią Prezydenta ${ }^{22}$; wkroczenie funkcjonariuszy Agencji Bezpieczeństwa Wewnętrznego do mieszkania studenta, który tworzył stronę internetową Antykomor.pl zawierającą negatywne opinie na temat sposobu sprawowania władzy przez urzędującego prezydenta ${ }^{23}$; usunięcie przez Marszałka Senatu fragmentu wystawy na temat katastrofy smoleńskiej prezentowanej w budynku sejmowym ${ }^{24}$; zatrzymanie, przewiezienie do komisariatu

nej zaliczyć należy organy władzy wykonawczej, a więc wszelkie organy, które nie są organami działającymi w zakresie władzy ustawodawczej i władzy sądowniczej. Zwraca przy tym uwage, że „Organ sprawuje władzę, ale sam władzą nie jest” (zob. E. Ochendowski, Prawo administracyjne. Czesść ogólna, Torun 2002, s. 217).

21 Stowarzyszenie Solidarni 2010 zostało powołane we wrześniu 2010 r. Z postanowień zawartych $\mathrm{w}$ statucie stowarzyszenia wynika, że jego celem jest przede wszystkim działanie na rzecz wolności słowa, prawdy i odwagi w debacie publicznej, rzetelności informacji i pluralizmu w mediach. Celem działania stowarzyszenia jest także „Rozwój Polski na bazie prawdy historycznej i tożsamości narodowej. Włączenie doświadczenia polskiego narodu w budowanie przyszłości Polski” (http://www.komitetpoparcia.pl/aktualnosci/statutStowarzyszenia_solidarni_2010,pnews,65.html). Wiosną 2011 r. członkowie Stowarzyszenia rozpoczęli protest pod Pałacem Prezydenckim na Krakowskim Przedmieściu ustawiając tam ogrodowy namiot, na którym wywieszono petycję z żądaniami m.in. dymisji premiera Donalda Tuska i powołania międzynarodowej komisji do zbadania przyczyn katastrofy smoleńskiej (zob. 4 postulaty Solidarnych 2010, http://solidarni2010.pl/n,461,8,4-postulaty-solidarnych-2010.html).

22 Barierki ogrodzity krzyż pod pałacem prezydenckim, komunikat z dnia 3 sierpnia 2010 r., http:/www.se.pl/wydarzenia/kraj/barierki-ogrodzily-krzyz-pod-palacem-prezydenckim-_148675.html.

${ }^{23}$ Prokurator o przeszukaniu ws. Antykomora.pl, komunikat z dnia 23 maja 2011 r., http://www.polskieradio.pl/5/3/Artykul/372270,Prokurator-o-przeszukaniu-ws-Antykomorapl.

${ }^{24}$ Senat cenzuruje czeska wystawę, Komunikat z dnia 26 maja 2011 r., http://www.fronda.pl/news/czytaj/tytul/senat_cenzuruje_czeska_wystawe_13449. 
i przesłuchanie dwóch młodych ludzi w związku z tym, że trzymali transparent z napisem „Przyszła pora na AntyKomora. Wolność słowa jest niezdrowa"25; nałożenia mandatów karnych na kwotę 500 zł na demonstrujących przez Kancelarią Premiera kibiców za to, że prezentowali transparent z napisem „Donald matole twój rząd obalą kibole”26; legitymowanie osób składających kwiaty na Krakowskim Przedmieściu, w celu upamiętnienia rocznicy katastrofy smoleńskiej ${ }^{27}$; zatarasowanie przez funkcjonariuszy Straży Miejskiej przejścia, a przez to uniemożliwienie parlamentarzystom wejście na teren uroczystości związanej z katastrofą smoleńską ${ }^{28}$.

Większość wskazanych czynności wykonywała Straż Miejska, inne spotkały się z reakcją policji albo były wykonywane przez funkcjonariuszy Biura Ochrony Rządu lub Agencji Bezpieczeństwa Wewnętrznego. Służby te posłużyły się w pewnych przypadkach środkami przymusu bezpośredniego ${ }^{29} \mathrm{~W}$ innych nakładano na uczestników mandaty karne, a najłagodniejszą formą reakcji było legitymowanie przypadkowych osób biorących udział w zgromadzeniach. Nie ulega wątpliwości, że działania te miały charakter represyjny, a ich skutkiem mogło być zaniechanie dalszej aktywności przez osoby, które spotkały się, choćby z łagodną reakcją funkcjonariuszy. Uczestnicy zgromadzeń zarzucali funkcjonariuszom służb porządkowych postawę arogancką, pełną buty i zdeterminowania ${ }^{30}$. Postawa ta jest zauważalna także w materiałach filmowych zarejestrowanych przez uczestników i udostępnionych na stronach internetowych ${ }^{31}$.

25 Nie będzie zarzutów za „Przyszła pora na AntyKomora. Wolność stowa jest niezdrowa, komunika z dnia 22 maja 2011 r., http://www.rmf24.pl/fakty/polska/ news-nie-bedzie-zarzutow-za-przyszla-pora-na-antykomora-wolnosc,nId,341395.

${ }^{26}$ Donald, matole, twój rząd obala kibole, komunikat z 7 maja 2011 r., http://niezalezna.pl/10128-donald-matole-twoj-rzad-obala-kibole.

27 F. Rdesiński, Sowieckie metody PO, „Gazeta Polska” z dnia 23 marca 2011 r., s. 4.

28 PiS skarży Straż, Straż - Brudzińskiego, komunikat PAP z dnia 18 kwietnia 2011 r., http://www.rp.pl/artykul/644839.html.

29 Solidarni 2010 złożyli zawiadomienie do prokuratury w sprawie zatrzymań i pobicia, komunikat z dnia 26 kwietnia $2011 \mathrm{r}$., http://wpolityce.pl/view/10910/Solidarni_2010_zlozyli_zawiadomienie_do_prokuratury_w_sprawie_zatrzyman_i_pobicia.html.

${ }_{30}$ T. Rakowski, Czuję narastajaca złość, „Uważam Rze” 2011, nr 17, s. 37.

31 T. Rakowski opisuje wrażenia po obejrzeniu filmów rejestrujących działania służb porządkowych na Krakowskim Przedmieściu w ten sposób: „Kiedy oglądam setny film spod pałacu, gdzie widzę młodych chłystków lżących starsze kobiety, 
Zaangażowanie w działaniu, niewątpliwie cenne w przypadku każdego innego zawodu, budzić może obawy co do jego apolityczności, a przez to także proporcjonalności zastosowanych środków, jeśli staje się reakcją aparatu władzy na realizację wolności wypowiedzi.

Najbardziej dotkliwe - jak się wydaje środki zostały zastosowane przez stołeczną Straż Miejską w ramach interwencji polegającej na usuwaniu namiotu Solidarnych 2010, kiedy wskutek zastosowania środków przymusu bezpośredniego przez funkcjonariuszy Straży Miejskiej obrażeń doznał dziennikarz „Gazety Polskiej” Michał Stróżyk ${ }^{32}$. Incydent ten stał się przyczyną interpelacji poselskiej złożonej przez sześciu parlamentarzystów do Ministra Spraw Wewnętrznych i Administracji ${ }^{33}$.

niewzruszonych policjantów, strażników miejskich pilnujących tulipanów albo zakuwających w kajdanki protestujących pod namiotem, kiedy patrzę na agresję skierowaną wobec operatora kamery, kiedy słyszę życzenia nihiliacji, kiedy czytam o petycji w sprawie delegalizacji największej partii opozycyjnej, kiedy jestem świadkiem zastraszania i grożenia "załatwię cię frajerze”, to czuję narastająca złość” (zob. T. Rakowski, Czuje narastajacq złość, „Uważam Rze” 2011, nr 17, s. 37).

${ }^{32}$ List w tej sprawie do Prezydent Miasta Warszawy wystosował Wicemarszałek Senatu Zbigniew Romaszewski, który zajście z udziałem Straży Miejskiej nazwał skandalicznym i przytoczył jego następujący przebieg: „Około godziny 16 pokojowo nastawionych demonstrujących otoczył kordon Straży Miejskiej. Funkcjonariusze zaczęli rozbierać namiot. Trzy osoby nie chciały wyjść poza kordon strażników. Wśród nich był dziennikarz „Gazety Polskiej” Michał Stróżyk, który z kamerą w ręku i laptopem, usiłował dokumentować całe zajście. Jeden z funkcjonariuszy zwrócił się do niego niegrzecznie, by nie przeszkadzał im w pracy. Pan Michał odpowiedział, że nie odejdzie, że jest dziennikarzem i bycie w tym miejscu to jego praca. W tym momencie został gwałtownie powalony na chodnik przez kilku funkcjonariuszy, którzy rzucili mu się na plecy. W wyniku uderzenia twarzą o płyty chodnikowe stracił ząb. Zakuto mu z tyłu ręce $\mathrm{w}$ kajdanki tak mocno, że utrudniono krążenie krwi. W ten sposób zakutego dźwignięto go za przedramiona, wyłamując mu barki. Michał Stróżyk od dnia 11 kwietnia 2011 roku przebywa w szpitalu na oddziale chirurgicznym. Ma wstrząs mózgu, uszkodzony kręgosłup. Jest w trakcie badań diagnostycznych, po których będzie dopiero można określić rozmiar doznanych obrażeń" (zob. Interwencja w sprawie pobicia przez stoleczna Straż Miejskq w dniu 11.04.2011 Michała Stróżyka, pismo z 15 kwietnia 2011 roku, http://www.romaszewski.pl/publikacje/2011_kwiecien-interwencja-w-sprawie-pobicia-przez-stoleczna-straz-miejska-w-dniu-11-04-2011-michala-strozyka-pismo-z-15-kwietnia-2011-roku).

33 Parlamentarzyści pytają m.in. o to na jakiej podstawie prawnej doszło do zatrzymania przez Straż Miejską Miasta Stołecznego Warszawy w obecności funkcjonariuszy Policji dziennikarza „Gazety Polskiej”; jakie postępowania zostały wszczęte 
Wśród formułowanych wobec Straży Miejskiej zarzutów podnoszono, że nie potrafi w humanitarny i godny funkcjonariusza państwowego sposób korzystać z przysługujących jej uprawnień, a jej działania stanowią zagrożenie dla życia i zdrowia obywateli, do służenia którym została powołana. Z. Romaszewski zwrócił uwagę, że ,zgodnie z ustawą o strażach gminnych, Strażnicy Miejscy mogą stosować środki przymusu bezpośredniego w postaci siły fizycznej jedynie w celu odparcia czynnej napaści, ujęcia osoby, zmuszenia do określonej czynności"34.

Za działania o charakterze ograniczającym wolność wypowiedzi uznawane są także zaniechania ze strony organów, inspekcji i służb. Nie podejmowały one bowiem interwencji wobec tych uczestników zgromadzeń, którzy zachowywali się wulgarnie, obscenicznie, stosowali groźby, znieważali, a niektóre działania należało kwalifikować jako nawoływanie do popełnienia przestępstwa ${ }^{35}$. Kierowane do organów ścigania zgłoszenia o podejrzeniu popełnienia przestępstwa, po wszczęciu postępowania

względem funkcjonariuszy Policji, obecnych w czasie zatrzymania przez Straż Miejską dziennikarza, którzy nie przerwali bezprawnego zatrzymania dokonanego przez strażników miejskich; jakie środki prawne zamierza zastosować Minister Spraw Wewnętrznych i Administracji względem komendanta Straży Miejskiej w Warszawie w związku z bezprawnym zatrzymaniem dziennikarza. Tymczasem zastępca komendanta Straży Miejskiej wyjaśniając działania funkcjonariuszy na Krakowskim Przedmieściu zaprzeczył jakoby stosowano wobec kogokolwiek środki przymusu, a poturbowanie dziennikarza ocenił jako przypadkowe i nieumyślne Zbigniew Włodarczyk, zastępca komendanta warszawskiej Straży Miejskiej, powiedział, że strażnicy wspierali wówczas pracowników Zarządu Dróg Miejskich, którzy chcieli usunąć namiot. Funkcjonariusze próbowali wyprowadzić spod namiotu Stróżyka, który nie chciał stamtąd wyjść. Jak mówił Włodarczyk, wówczas ktoś wbiegł na strażników i przewrócił zarówno funkcjonariuszy, jak i Stróżyka. Po upadku dziennikarz „Gazety Polskiej” miał otarcie naskórka na głowie. Został odwieziony na obserwację do szpitala (zob. Stużby: nie stosowano środków przymusu $10 \mathrm{IV}$ przed Pałacem (opis), komunikat PAP z dnia 12 maja 2011 r., http://lubczasopismo.salon24.p1/smolenskarocznica/news/132522,sluzby-nie-stosowano-srodkow-przymusu-10-iv-przed-palacem-opis).

${ }^{34}$ Z. Romaszewski podkreślał, że w sprawie M. Stróżyka nie było żadnych podstaw do podejmowania interwencji, a cała agresja była po stronie funkcjonariuszy (zob. Interwencja w sprawie pobicia przez stoteczna Straż Miejskq w dniu 11.04.2011 Michała Stróżka, pismo z 15 kwietnia 2011 roku, http://www.romaszewski.pl/publikacje/2011_kwiecien-interwencja-w-sprawie-pobicia-przez-stoleczna-straz-miejska-w-dniu-11-04-2011-michala-strozyka-pismo-z-15-kwietnia-2011-roku).

35 T. Rakowski, Czuję narastajaca złość, „Uważam Rze” 2011, nr 17, s. 36. 
kończą się umorzeniem z powodu niewykrycia sprawców ${ }^{36}$. Zauważalna była zatem dysproporcja w przejawianej przez służby odpowiedzialne za bezpieczeństwo i porządek publiczny aktywności i intensywności działań, a także stosowanych środkach.

Ingerencja w wolność wypowiedzi może przybierać różne formy działania organów odpowiedzialnych za zapewnienie bezpieczeństwa i porządku publicznego. Może zatem polegać na wymierzaniu kar administracyjnych, a także stosowaniu utrudnień w podejmowaniu działań mieszczących się w danej sferze wolności ${ }^{37}$. Oznaczać może także nakładanie barier finansowych, w postaci opłat i podatków oraz utrudnień proceduralnych przy dopełnianiu różnego typu formalności. Za rodzaj ingerencji może zostać uznane także ograniczanie dostępu do dóbr materialnych, koniecznych do korzystania $\mathrm{z}$ danej wolności ${ }^{38}$. W doktrynie nie budzi wątpliwości pogląd, że formą ograniczenia wolności jest stosowanie przymusu państwowego. Przyjmuje się, że „stwarzanie sytuacji przymusowych, zmuszających kogoś do wyboru między spełnieniem uciążliwego dlań czynu (podjęciem, względnie zaniechaniem odpowiedniego działania) a narażeniem się na jakieś zło wymierzane za niezrealizowanie owego czynu, jest jednym z tradycyjnie stosowanych zabiegów socjotechnicznych, w szczególności w postaci sankcjonowania ustanawianych przez jakąś osobę czy instytucję norm postępowania"39.

36 Umorzone zostało śledztwo w sprawie znieważenia przedmiotu czci religijnej, do którego doszło w czasie zgromadzeń pod Kancelarią Prezydenta na Krakowskim Przedmieściu w sierpniu 2011 r. (zob. T. Rakowski, Czuję..., s. 36). Z powodu niewykrycia sprawców umorzone zostało także śledztwo w sprawie pobicia jednego z obrońców krzyża (zob. Sprawa Klusika umorzona, http://wirtualnapolonia.com/ 2011/07/09/sprawa-klusika-umorzona/).

37 W literaturze zwraca się uwagę, że procesy sądowe nie są jedynymi formami nacisku zmierzającymi do tłumienia niewygodnych opinii i poglądów. G. Gzella analizując formy nacisku stosowane wobec redaktorów polskich gazet pod zaborem pruskim zauważa, że ,mobilizowano przeciw nim także rozbudowany aparat urzędniczy, reprezentowany przez pracowników rejencji, landratów, policjantów, nauczycieli i członków organizacji społecznych. W XIX stuleciu i w pierwszych latach wieku XX wprowadzono dodatkowe utrudnienia: zakazywano sprzedaży czasopism na dworcach, zabraniano rozprowadzania ich wśród rekrutów, nie dopuszczano do przesyłki gazet przez pocztę" (Zob. G. Gzella, Przed wysokim sqdem. Procesy prasowe polskich redaktorów czasopism dla chłopów w zaborze pruskim, Toruń 2004, s. 266).

38 Ibidem, s. 69.

39 Z. Ziembiński, Analiza pojęcia czynu, Warszawa 1972, s. 114. 
Prawo administracyjne ${ }^{40}$, które normuje wypełnianie przez organ administracji publicznej funkcji policji ${ }^{41}$, tworzy sferę aktywności administracyjnej, ale - jak się zauważa w doktrynie - tworzy także sferę praw oraz wolności obywatelskich. I tam, gdzie działalność administracji nie jest w sposób wyraźny dopuszczona, tam rozciaga się sfera wolności obywatelskich, „która nie może być ścieśniona rozszerzającą interpretacją" ${ }^{2}$. W doktrynie nie budzi wątpliwości stanowisko, że administracja publiczna, jeśli wkracza w sferę praw i obowiązków obywatela musi mieć wyraźne upoważnienie ustawy. Działanie na podstawie prawa oznacza: 1) działanie na podstawie obowiązującej normy prawnej; 2) prawidłowe ustalenie znaczenia normy prawnej; 3) niewadliwe dokonanie subsumcji; 4) prawidłowe ustalenie następstw prawnych ${ }^{43}$.

Ograniczenie wolności, ujmowane niekiedy w doktrynie jako ingerencja, polega na utrudnianiu zachowań mieszczących się w danej sferze wolności objętej ochroną konstytucyjną ${ }^{44}$. Wolność jest w literaturze definiowana jako „zdolność do działania niezależnego od wpływu innych podmiotów oraz podejmowania decyzji w zgodności z aktem własnego wyboru zdeterminowanego przez całokształt czynników historycznych, społecznych i kulturowych, jak również uwarunkowanego poznaniem i uznaniem obiektywnych konieczności" ${ }^{45}$. Jakkolwiek wiele pojawia się definicji wolności, to uzasadnione wydaje się zawsze założenie, że formą ograniczenia wolności wypowiedzi jest każde działanie utrudniające swobodne z niej korzystanie, chociaż utrudnienia te niekiedy będzie należało uznać za dopuszczalne ${ }^{46}$. Ustanowienie prawnych gwarancji wol-

${ }^{40} \mathrm{~W}$ doktrynie pojawia się wiele definicji prawa administracyjnego. E. Ochendowski definiuje je jako „zespół norm, które regulują administracyjną działalność państwa" (zob. E. Ochendowski, Prawo administracyjne. Część ogólna, Toruń 2002, s. 29). J. Starościak ujmuje jako „gałąź prawa, która reguluje działalność organów państwowych, podejmowaną w celu wykonywania ustalonych prawem zadań organizatorskich wypełnianych w swoistych formach działania" (zob. J. Starościak, w: J. Starościak, E. Iserzon, Prawo administracyjne, Warszawa 1963, s. 15-16).

41 E. Leoński, Materialne prawo administracyjne, Warszawa 2003, s. 17.

42 J. Starościak, Źródła prawa administracyjnego, Warszawa 1976, s. 167; cyt. za: B. Adamiak, J. Borkowski, Kodeks postępowania administracyjnego. Komentarz, Warszawa 2009, s. 49.

43 B. Adamiak, J. Borkowski, Kodeks..., s. 52.

44 K. Wojtyczek, Granice..., s. 66.

45 J. Sobczak, Prawo..., s. 28-29.

46 Zawarte w regulacjach prawnych postanowienia ograniczające wolność wypowiedzi mogą przybierać formę wyjątków ex definitione ujmowanych jako zakazy 
ności wypowiedzi oraz wyróżnienie rozwiązań prawnych dopuszczających wprowadzanie jej ograniczeń nie przesądza o jej faktycznym istnieniu w państwie. Dopiero bowiem aktywność jednostek, grup społecznych i całego społeczeństwa, a w zetknięciu z tą aktywnością - rodzaj, tryb i zakres działania organów państwa wyznaczać będzie zakres faktycznie istniejącej wolności w danym społeczeństwie.

Ocena dopuszczalności ograniczenia wolności wypowiedzi jest uzależniona nie tylko od tego, czy działanie to zostało unormowane w ustawie, ale także od tego czy zastosowane metody i środki nie były nadmierne w stosunku do celu, jaki podmiot ingerujący chciał osiagnąć. O ile zatem celem jest zapewnienie porządku i bezpieczeństwa publicznego w czasie demonstracji, zgromadzeń, pikiet czy też innych form wyrażania poglądów i opinii, należy badać użyte przez służby porządkowe środki pod kątem ich niezbędności, celowości oraz minimalizacji skutków $^{47}$. Ocena ta jest konieczna, zwłaszcza w związku z zastosowaniem środków przymusu bezpośredniego i obowiązuje wszystkie służby odpowiedzialne za zapewnienie bezpieczeństwa i porządku publicznego. W doktrynie kryteria te uznawane są za ogólne reguły, zgodnie, z którymi należy postępować zarówno przed podjęciem decyzji o użyciu środka przymusu, jak też $\mathrm{w}$ czasie jego stosowania oraz po zaprzestaniu stosowania tego środka ${ }^{48}$.

W literaturze wyodrębnia się niekiedy „zasady ogólne” działania organów powołanych do sprawowania funkcji policji ${ }^{49}$. Jedną $\mathrm{z}$ naczelnych jest zasada niezbędności stosowanych środków, która nakazuje stosowanie przymusu tylko $\mathrm{w}$ granicach niezbędnych do usunięcia za-

i nakazy, mogą być także regulowane za pomocą klauzul limitacyjnych albo klauzul derogacyjnych. Zauważa się jednocześnie, że sankcjonowanie wypowiedzi objętych wyjątkami, a zatem wypowiedzi, które są skutkiem działań nakazanych lub zakazanych, jest uzależnione od spełnienia wymogów klauzuli limitacyjnej. Klauzule limitacyjne zawierać winny natomiast zamknięty katalog prawowitych celów, których osiagnięciu służyć ma ograniczenie wolności wypowiedzi. Do klauzul limitacyjnych zaliczono zarówno art. 31 ust. 3 Konstytucji jak i art. 10 ust. 2 Konwencji o ochronie praw człowieka. Klauzule derogacyjne wskazują na dopuszczalność wkraczania w całą substancję wolności wypowiedzi, w tym prawo do posiadania własnych poglądów (zob. R. Mizerski, Wolność ekspresji, w: Prawa człowieka..., s. 338).

47 B. Kurzępa, Ustawa..., s. 185.

48 A. Szymański, D. Walczak, E. Krzyżak-Szymańska, Podręcznik policjanta stużby prewencji, cz. I, Warszawa 2004, s. 148.

49 Z. Leoński, Materialne..., s. 194. 
grożenia. Odstępuje się od użycia środka przymusu wtedy, gdy użycie przymusu nie przyniosło - i wiadomo już, że nie przyniesie - pożądanego rezultatu. Zasada ostrzeżenia polega na obowiązku funkcjonariusza wcześniejszego wezwania do zachowania zgodnego z prawem, a następnie uprzedzeniu o użyciu przymusu, gdy wezwanie to nie przyniesie skutku. Zasady minimalizacji skutków formułują obowiązek używania środków przymusu bezpośredniego w sposób wyrządzający możliwie najmniejszą dolegliwość, w szczególności niepowodujący uszkodzenia ciała lub rozstroju zdrowia ${ }^{50}$.

Przepisy regulujące uprawnienia służb mundurowych nie wyłączają żadnych grup podmiotów, wobec których stosowanie w ustawach środków, byłoby niedozwolone ${ }^{51}$. Z zasad konstytucyjnych oraz wydanych na ich podstawie przepisów szczegółowych wynikają zakazy stosowania środków przymusu wobec osób objętych immunitetem materialnym bądź formalnym ${ }^{52}$. W art. 105 ust. 2 i 3 Konstytucji uregulowano tzw. immunitet nietykalności, którym objęto posłów i senatorów. W przepisie tym zakazano stosowania środków w postaci zatrzymania lub aresztowania, z wyjątkiem sytuacji, gdy poseł lub senator zostałby ujęty na gorącym uczynku przestępstwa. Wobec tych, szczególnych regulacji, może zastanawiać sposób przeprowadzania interwencji przez funkcjonariuszy w czasie uroczystości na Krakowskim Przedmieściu związanych z rocznicą katastrofy smoleńskiej, kiedy uniemożliwiono części posłów swobodne dotarcie na uroczystości, a niektórzy z nich doznali lekkich obrażeń w związku z zastosowaną przez funkcjonariuszy blokada ${ }^{53}$.

Działania z zakresu bezpieczeństwa i porządku publicznego, by zostały uznane za dopuszczalne, muszą być podejmowane nie tylko na

50 B. Kurzępa, Ustawa..., s. 185.

51 Wyjątek od tej zasady stanowią regulacje dotyczą kobiet w widocznej ciąży, wobec których środki przymusu bezpośredniego mogą być stosowane z daleko idącą ostrożnością.

52 K. Indecki, A. Liszewska, Prawo karne materialne. Nauka o przestępstwie, karze i środkach penalnych, Warszawa 2002, s. 350-355.

53 Żądanie złożenia wyjaśnień w tej sprawie od Ministra Spraw Wewnętrznych i Administracji złożyło w drodze interpelacji sześciu posłów. (Zob. Posłowie na Sejm Z. Girzyński, A. Jaworski, L. Krasulski, Z. Kozak, M. Kraczkowski, S. Pięta, Zapytanie poselskie $w$ sprawie bezprawnego działania stużb mundurowych $w$ czasie likwidacji manifestacji stowarzyszenia Solidarni $2010 i$,,Koliber” $w$ dniu 11 kwietnia 2011 r., złożone na ręce Marszałka Sejmu w dniu 14 kwietnia 2011 r.). 
podstawie prawa, ale także mieścić się w jego granicach. W odniesieniu do działań służb mundurowych granic tych należy poszukiwać zarówno w ogólnych zasadach prawa zawartych w Konstytucji RP, jak również w klauzulach limitujących zakres stosowanych interwencji zawartych w przepisach szczegółowych odrębnie normujących pracę tych służb. Za niedopuszczalne należałoby zatem uznać takie działania, które naruszają istotę praw i wolności konstytucyjnych, w tym także wolności wypowiedzi. W sposób niebudzący watpliwości normy prawne eksponują obowiązek respektowania godności ludzkiej oraz przestrzegania i ochrony praw człowieka (art. 14 ust. 3 ustawy o policji) przez policjantów wykonujących czynności służbowe. Obowiązek ten w równym stopniu dotyczy funkcjonariuszy straży gminnych. W art. 1 ust. 2 ustawy o strażach gminnych ustawodawca wskazał, że „Straż spełnia służebną rolę wobec społeczności lokalnej, wykonując swe zadania z poszanowaniem godności i praw obywateli”. Zwraca uwagę nałożony na funkcjonariuszy obowiązek poszanowania nie tylko godności ludzkiej, jako wartości posiadającej szczególną rangę w hierarchii dóbr konstytucyjnych, ale także poszanowania praw człowieka. W doktrynie zwrócono uwagę na służebną rolę straży gminnej względem lokalnej społeczności. Nie może to zatem być rola władcza, dominująca, gdyż nadzór nad działalnością straży sprawuje wójt, burmistrz, prezydent miasta ${ }^{54}$.

Za dopuszczalnością ingerencji w wolność wypowiedzi przemawiać mogą zatem względy bezpieczeństwa i porządku publicznego. Nie będą one jednak usprawiedliwiały stosowania środków nieproporcjonalnych do celu, jakiemu miały służyć. Ocena legalności podejmowanych przez służby porządkowe interwencji uwzględniać winna nie tylko istnienie prawnego upoważnienia lub przyznanej kompetencji stanowiących podstawę podjętych czynności, ale także rozmiar wywołanych skutków faktycznych stanowiących formę ingerencji w jedno $\mathrm{z}$ fundamentalnych praw człowieka, jakim jest wolność wypowiedzi. Należy zwrócić uwagę, że każda z biorących udział w zabezpieczaniu zgromadzeń publicznych służb, działa w oparciu o odrębne uregulowania prawne ${ }^{55}$. W każdej

54 B. Kurzępa, E. Kurzępa-Czopek, Ustawa ..., s. 45.

55 Pracę policji reguluje ustawa o Policji z dnia 6 kwietnia 1990 r., Dz. U. 1990, $\mathrm{Nr} 30$ poz. 179 z pózn, zm; pracę Agencji Bezpieczeństwa Wewnętrznego - ustawa $o A B W$ z dnia 24 maja 2002 r., Dz. U. 2002, Nr 74, poz. 676 z pózn. zm., pracę straży gminnych - ustawa o strażach gminnych z dnia 29 sierpnia 1997 r., Dz. U. Nr 123, poz. 779 z późn. zm). 
z regulacji prawnych znalazły się unormowania nieostre, nieposiadające legalnych definicji, przyjmujące formułę klauzul pozwalających na szeroką interpretację przysługujących służbom kompetencji. W art. 11 ustawy o Policji umieszczono regulację, która upoważnia zarówno organy administracji rządowej, jak i organy samorządu terytorialnego do zlecania policji czynności służących zapewnieniu porządku publicznego ${ }^{56}$. Nie jest jednak jasne w jakich okolicznościach zlecenie działań policji powinno nastąpić. Szerokiej i niejednoznacznej interpretacji poddaje się także użyte w treści tego artykułu zalecenie „,przywrócenia stanu zgodnego z prawem". Wattpliwości co do zakresu i celu działania Policji budzić może także treść art. 1, w którym ustawodawca założył, że policja, jako umundurowana i uzbrojona formacja służy społeczeństwu i jest przeznaczona do ochrony bezpieczeństwa ludzi i utrzymywania bezpieczeństwa i porządku publicznego. Rozbieżności pojawiają się bowiem w odniesieniu do użytych pojęć „,bezpieczeństwo” i „porządek publiczny" ${ }^{, 57}$.

Ustawodawca przyznał policji szerokie uprawnienie w zakresie reagowania na naruszenia prawa poczynając od legitymowania osób w celu ustalenia tożsamości, poprzez zatrzymanie, kontrolę osobistą przeszukanie, stosowanie technik operacyjnych aż po użycie środków przymusu bezpośredniego. Kolejne ustawy nowelizujące poszerzały zakres uprawnień policji przewidując m.in. możliwość wykorzystania uzbrojonych oddziałów i pododdziałów policji na wypadek zagrożenia bezpieczeństwa publicznego lub niebezpiecznego zakłócenia porządku publicznego (art. 18). O uruchomieniu uzbrojonych oddziałów i pododdziałów policji decyduje Prezes Rady Ministrów (art. 18 ust. 1), albo minister właściwy do spraw administracji i bezpieczeństwa publicznego (art. 18 ust. 2). Dopuszczalne jest także użycie oddziałów policji z jednostkami sił zbrojnych (art. 18 ust. 3,4$)$.

Ustawa wskazuje na okoliczności, w jakich dopuszczalne jest stosowanie każdego z przewidzianych prawem środków. Funkcjonariusz jest zobowiązany do wykazania celowości ich zastosowania. O ile zatem

56 Art. 11 ustawy o Policji posiada następujące brzmienie: „Właściwe organy Policji na żądanie wojewody, wójta lub burmistrza (prezydenta) miasta są obowiązane do przywrócenia stanu zgodnego z porządkiem prawnym lub podjęcia działań zapobiegających naruszeniu prawa".

57 A. Misiuk, Administracja porzqdku i bezpieczeństwa publicznego. Zagadnienia prawno-ustrojowe, Warszawa 2008, s. 16-19. 
ustawa o policji stanowi, że legitymowanie odbywa się w celu ustalenia tożsamości, o tyle dokonywanie kontroli osobistej będzie uzasadnione tylko w wypadku istnienia uzasadnionego podejrzenia popełnienia czynu zabronionego pod groźbą kary. Środki przymusu bezpośredniego mogą zostać zastosowane wyłącznie w razie niepodporządkowania się wydanym na podstawie prawa poleceniom (art. 16 ust. 1) i tylko wówczas, gdy odpowiadają one potrzebom wynikającym z istniejącej sytuacji i jeśli są one niezbędne do osiagnięcia podporządkowania się wydanym poleceniom (art. 16 ust. 2). Sedno ustaleń tkwi zatem w stwierdzeniu, czy zastosowane środki wynikały $\mathrm{z}$ istniejącej potrzeby i były niezbędne. W podobny sposób uprawnienia dotyczące stosowania odpowiednich środków reguluje ustawa o strażach gminnych. Straż Gminna wyposażona została dodatkowo w środki oddziaływania wychowawczego takie jak udzielanie pouczeń, zwracanie uwagi bądź ostrzeganie (art. 12 ust. 1 pkt 1 ustawy o strażach gminnych).

Do uprawnień, które łatwo mogą być nadużywane przez funkcjonariuszy Straży Miejskiej należy uprawnienie do wydawania poleceń (art. 12 ust. 1 pkt 7), co oznacza, że strażnik jest władny nakazać osobie sposób określonego zachowania się w danej sytuacji. Z ustawy nie wynika wprost, że niezastosowanie się do wydanego polecenia uprawnia funkcjonariusza do zastosowania przymusu fizycznego. W art. 14 ust. 1 przyjmuje się bowiem, że „Strażnik może stosować środki przymusu bezspośredniego wobec osób uniemożliwiających wykonanie przez niego zadań określonych w ustawie". W doktrynie zwraca się uwagę, że formuła zawarta w tym przepisie niewiele wyjaśnia ${ }^{58}$. Za działanie uniemożliwiające strażnikowi wykonanie jego zadań można bowiem uznać zarówno zachowania agresywne, jak i niewykazujące cech agresji, ale uciążliwe. Zwraca się zarazem uwagę, że uprawnienia straży miejskiej są daleko idące, niejednokrotnie drastyczne w formie, a skutki realizacji tych uprawnień niejednokrotnie łączą się z przykrymi odczuciami osób, wobec których zostały użyte ${ }^{59}$.

Działania podejmowane przez Straż Miejską nie muszą być protokołowane. Skutkuje to daleko idącymi rozbieżnościami w opisie przebiegu interwencji, czego przykładem jest działanie Straży Miejskiej w Warszawie wobec Michała Stróżyka. Przepis art. 12 ust. 1b nie usta-

58 B. Kurzępa, E. Kurzępa-Czopek, Ustawa o strażach gminnych z komentarzem, Toruń 2011, s. 184.

59 Ibidem, s. 182. 
nawia żadnego obowiązku informowania osoby kontrolowanej przez strażnika o przysługującym mu prawie do złożenia wniosku o sporządzenie protokołu. W doktrynie podnosi się, że jest to niewątpliwie niedopatrzenie ze strony ustawodawcy i de lege lata należy postulować, aby strażnik był zobligowany w każdym przypadku do udzielenia takiego pouczenia osobie kontrolowanej. Winien też zostać ustawowo oznaczony termin do sporządzenia takiego protokołu ${ }^{60}$.

Sankcją, odczuwaną jako szczególnie dolegliwa, są grzywny nakładane w postępowaniu mandatowym przez funkcjonariuszy Straży Miejskiej na uczestników wieców, pikiet i zgromadzeń. Zarówno rodzaj popełnionego wykroczenia, jak i wysokość nałożonej grzywny może rodzić pytania o rzeczywisty cel działania służb porządkowych. Można przypuszczać, że dotyczy on nie tylko przywrócenia stanu zgodnego z prawem, ale także - a może przede wszystkim - służy osłabieniu intensywności społecznych protestów. Za przejaw ograniczenia wolności wypowiedzi może zostać uznane nakładanie grzywien w wysokości 500 zł na pikietujących kibiców. Szczególnie zwraca uwagę wysokość grzywny, jeśli zważyć, że w postępowaniu mandatowym grzywnę można wymierzać w wysokości od 20 do $500 \mathrm{zł}$. W doktrynie zwraca się uwagę, że jej rozmiary powinny zostać uzależnione od warunków osobistych i rodzinnych, dochodów sprawcy i możliwości zarobkowych (art. $24 \S 3$ Kodeksu wykroczeń) ${ }^{61}$. Grzywna powinna bowiem stanowić dolegliwość dla ukaranego, a nie dla jego rodziny, a ponadto powinna być realna i możliwa do wyegzekwowania $^{62}$.

Formy reagowania na czynności faktyczne funkcjonariuszy służb odpowiedzialnych za porządek i bezpieczeństwo, zwłaszcza gdy nie są to czynności protokołowane, uniemożliwiają skuteczną ochronę praw i wolności. Za niewystarczający należy uznać tzw. rekurs hierarchiczny, czyli możliwość złożenia skargi na niższy organ do organu wyższego ${ }^{63}$. Ograniczenie możliwości reakcji pokrzywdzonego wyłącznie do tego środka charakteryzuje państwo, w którym prawo jest wiążące dla obywatela, ale nie wiąże administracji. Z. Leoński zauważa, że początkowo podstawą ingerencji w wolności jest powołanie się przez organ władzy na

60 Ibidem, s. 175.

${ }^{61}$ Ustawa Kodeks wykroczeń z dnia 20 maja 1971 r., t.j. Dz. U. 2007, Nr 109, poz. 756.

62 B. Kurzępa, Kodeks wykroczeń, Komentarz, Warszawa 2008, s. 137.

63 Z. Leoński, Nauka administracji, Warszawa 2002, s. 29. 
konieczność odwrócenia grożących obywatelom szkód i zapewnienia bezpieczeństwa. Prowadzi to z czasem do nieograniczonej władzy, dla której wystarczy powołanie się na interes publiczny lub dobro poddanych, aby móc wkroczyć w sferę ich praw i wolności ${ }^{64}$. Model liberalnego państwa prawnego tym różni się od innych, że dąży do ograniczenia wpływu administracji na obywateli w stopniu maksymalnym. Najważniejszą zasadą staje się ochrona porządku prawnego, ale jest to ochrona przede wszystkim przed naruszeniami go ze strony administracji i zapewnienia wolności obywatelskich. W konsekwencji winno to prowadzić do związania administracji ustawą.

Ocena dopuszczalności działań podjętych przez funkcjonariuszy służb porządkowych wobec osób korzystających z wolności wypowiedzi wymaga uwzględnienia trzech przesłanek: 1) proporcjonalności siły reakcji i zastosowanych środków w stosunku do skali istniejącego zagrożenia; 2) zgodności działania $z$ przysługującym $w$ danych okolicznościach uprawnieniem oraz 3) oceny czy podjęte działanie mieści się w granicach prawa. Należy bowiem zwrócić uwagę, że tylko takie działanie może zostać usprawiedliwione, które nie tylko zostało podjęte na podstawie prawa, ale nadto mieści się w jego granicach.

Inaczej może natomiast kształtować się ocena ingerencji w indywidualnie realizowaną wolność wypowiedzi. Naruszeniem sfery wolności wypowiedzi, w wymiarze indywidualnym, były działania podjęte przez Agencję Bezpieczeństwa Wewnętrznego wobec Roberta Frycza, autora strony internetowej Antykomor.pl, na której od sierpnia 2010 r. gromadzone były materiały o prezydencie Bronisławie Komorowskim. 25 maja 2011 roku do mieszkania autora strony - na podstawie postanowienia Prokuratury Rejonowej w Tomaszowie Mazowieckim - weszło sześciu funkcjonariuszy Agencji Bezpieczeństwa Wewnętrznego oraz dwóch policjantów. Przeszukali je, zabezpieczyli laptop oraz inne nośniki danych. Autor po ich wyjściu zdecydował się na zamknięcie strony ${ }^{65}$. Autor strony złożył do sądu zażalenie na postanowienie prokuratury o przeszukaniu i zleceniu tych czynności ABW, sąd jednak zażalenia nie uwzględnił. W ustnym uzasadnieniu sąd stwierdził, że przeszukanie nie było konieczne, ale jednocześnie uznał, że zlecenie tych czynności ABW było uzasadnione, gdyż ,policja nie miałaby możliwości technicznych prze-

64 Ibidem, s. 29.

65 Są nie uznat zażalenia AntyKomora, komunikat PAP z dnia 9 czerwca 2011 r., www.rp.pl. 
prowadzenia analizy informatycznej zabezpieczonych nośników informacji" ${ }^{66}$. Robert Frycz złożył także do prokuratury zawiadomienie o podejrzeniu popełnienia przestępstwa przez funkcjonariuszy ABW i prokuratora oraz działanie na szkodę interesu publicznego i prywatnego. Prokuratura Rejonowa w Sieradzu po przeprowadzeniu czynności sprawdzających odmówiła wszczęcia śledztwa w tej sprawie. Zdaniem sieradzkiej prokuratury nie doszło do przekroczenia uprawnień, ponieważ przepis z art. 21 ust. 2 ustawy o ABW i Agencji Wywiadu dopuszcza możliwość zlecania czynności ABW, również wynikających z Kodeksu postępowania karnego ${ }^{67}$. Podjęte przez ABW czynności mają związek z prowadzonym przez Prokuraturę w Tomaszowie Mazowieckim śledztwie w sprawie zamieszczania na stronie AntyKomor.pl treści znieważających Prezydenta RP, co stanowi występek z art. 135 § 2 k.k.

Do faktycznego ograniczania wolności wypowiedzi dochodzi także w związku z toczącymi się procesami o naruszenie dóbr osobistych, których uczestnicy, pomimo formalnych gwarancji prawnych zapewnionych w normach regulujących procedurę cywilną i karną, nie dysponują takim samym arsenałem możliwości i środków. Słusznie zauważa jeden z uczestników procesu, że zwykły, skromny człowiek jest bezsilny w starciu procesowym $z$ koncernem medialnym ${ }^{68}$. Nie ulega wątpliwości, że zarówno wynagrodzenie dla pełnomocnika procesowego, jak i koszty sądowe, a także możliwości związane z gromadzeniem materiału dowodowego, powoływaniem świadków, a nawet kosztami dojazdu mogą stawiać uczestników procesu w całkowicie odmiennej sytuacji.

66 Ibidem.

${ }^{67}$ Sprawa „Antykomor.pl”: nie będzie postępowania w sprawie przekroczenia uprawnień przez $A B W$, http://www.hfhrpol.waw.pl/obserwatorium/index.php?option=com_content\&view $=$ article $\&$ id $=3875$ : sprawa-antykomorpl-nie-bdzie-postpowania- w-sprawie-przekroczenia-uprawnie-przez-abw\&catid=40:zkraju\&Itemid=34.

68 A. Klusik, analizując treść żądania pozwu zauważa „Gdyby powiedziano tylko, że mam przeprosić, to kto wie, jakby ta sprawa dalej się potoczyła. Zażądano jednak ode mnie dodatkowo wpłaty 5 tys. zł na cel charytatywny - co dla mnie jest sumą abstrakcyjną [...] Dla mnie oznacza to 10 miesięcy renty bez jedzenia. Więc proszę zwrócić uwagę na tę ogromną różnicę w położeniu. Być może takie żuczki jak ja są po to, by pokazać, że ten król jest nagi i śmieszny. Dla nich nie ma znaczenia, że nazywam się Klusik. Oni przyjęli zasadę, by tępić wszystkich, którzy mówią coś niewygodnego". (Zob. J. Dytkowski, Żaden z moich świadków nie zostat dopuszczony do zeznań, „Nasz Dziennik” z 6 lipca 2011 r., s. 5). A. Klusikowi został wytoczony proces o naruszenie dóbr osobistych przez „Gazetę Wyborczą” w związku wyrażeniem opinii, że ,jest to organizacja przestępcza i wroga naszej cywilizacji”. 
Wydaje się także, że sposób organizacji pracy sądu i prowadzenia postępowania przez sędziego orzekającego może mieć charakter faktycznego ograniczenia wolności wypowiedzi ${ }^{69}$. Ma to o tyle istotne znaczenie, że niektóre procesy przybierają formę wydarzeń publicznych, odbywających się z udziałem publiczności i szeroko relacjonowanych przez prasę.

Odrębnym zagadnieniem jest także kwestia legitymacji procesowej, a w szczególności ustalenie, czy naruszenie dóbr osobistych redaktora naczelnego gazety jest równoznaczne z naruszeniem dóbr wydawcy. Negatywna odpowiedź na to pytanie zmieniłaby sytuację procesową stron w taki sposób, że zastępstwo procesowe mogłoby być wykonywane jedynie w imieniu powoda jako osoby fizycznej, a nie, jak ma to obecnie miejsce, osoby prawnej. Na marginesie rozważań, świadomie pozostawiono kwestie treści i formy wypowiedzi, jako wymagające odrębnej analizy. Zwrócić należy jednak uwagę, że dla właściwej ochrony wolności wypowiedzi nie powinny pozostawać bez znaczenia okoliczności udzielania wypowiedzi (reakcja na opublikowany wcześniej w tej samej gazecie materiał obraźliwy dla rodziny pozwanego), które następnie zostają objęte treścią pozwu, a także osobiste przymioty uczestników procesu, a w szczególności wykonywana działalność twórcza lub zawodowa (poeta).

Wolność wypowiedzi objawia się poprzez wielość zróżnicowanych opinii i form aktywności. Jej zdeformowanym kształtem jest uniformizacja opinii i - jak zauważa W. Sokolewicz - ,uczynienie z niej narzędzia legitymizacji i umocnienia władzy, dysponującej cenzurą i innymi środkami wpływania na treści upowszechniane przez środki masowej komunikacji”, ${ }^{\prime}$. Podejmowanie, w ramach struktur państwowych, działań zmierzających do blokowania, w sensie faktycznym, publicznej prezentacji opinii i poglądów zawsze będzie mogło zostać uznane za sprzeczne z zasadą wolności wypowiedzi. Analiza okoliczności związanych z działaniami służb odpowiedzialnych za przestrzeganie porządku i bezpieczeń-

69 W sprawozdaniu z procesu o naruszenie dóbr osobistych A. Michnika przez J. M. Rymkiewicza zauważono: „W ścisku, ponieważ sąd wyznaczył na ten cel niewielką salkę oczekiwano na początek rozprawy. Było tak tłoczno, że nie wpuszczono żony i syna poety (pozwanego). Zgromadzeni, którzy nie mieli wątpliwości, że to celowe działanie zaczęli wówczas skandować: Większa sala!; Jawność zgromadzeń!; Wolność narodu!; Wolność poety!; Wolność słowa!; „Przyjdzie pora na redaktora!” (Zob. Wolność Poety, „Gazeta Polska” z 23 marca 2011 r., s. 11).

70 W. Sokolewicz, Prasa i Konstytucja, Warszawa 2011, s. 35. 
stwo publiczne wskazuje, że nie zawsze istnienie nominalnych gwarancji wolności wypowiedzi, choćby nawet zawartych w aktach prawnych posiadających najwyższą rangę w hierarchii źródeł prawa, zapewnia jej faktyczne obowiązywanie. Podobnie, nominalne obowiązywanie norm regulujących zasady wprowadzania ograniczeń wolności wypowiedzi, nie oznacza, że na innych polach aktywności, niewymierzonych wprost przeciwko wolności wypowiedzi, może - w sposób faktyczny - dochodzić do jej ograniczania.

\title{
The activity of security agencies and law enforcement as forms of preventive interference with the freedom of speech
}

\begin{abstract}
Summary
The paper demonstrates (by means of description and analysis) that the following activities of the law enforcement organs exemplify the limitation of the freedom of speech: (1) removal of the tent of the Solidarni 2010 movement from Krakowskie Przedmieście in Warsaw; (2) the erection of safety barriers in front of a group of people praying before a cross standing in front of the Chancellery of the President of Poland; (3) the Internal Security Agency entering the apartment of a student who designed the Antykomor.pl website, publishing negative opinions about the way the incumbent Polish President is exercising his office; (4) the removal by the Speaker of the Senate of part of an exhibition about the Smolensk catastrophe presented in the Parliament building; (5) arresting two young men and taking them to the police station to be questioned for holding a banner reading "It's time for Antykomor. Freedom of speech is unhealthy;" (6) imposing fines of PLN 500.00 (roughly equivalent to EUR 125) on football fans demonstrating in front of the Chancellery of the Prime Minister with a banner reading "Donald, you moron, football fans will topple your government;" (7) checking the IDs of people laying flowers in Krakowskie Przedmieście to commemorate the anniversary of the Smoleńsk catastrophe; and (8) the Municipal Guard blocking the way, in order to prevent members of the Polish parliament from attending a celebration commemorating the Smoleńsk catastrophe.
\end{abstract}

